\title{
From the Change of the Pattern to the Change in the Pattern. The Trilateral Game in the Italian Intergovernmental Relations
}

\author{
Silvia Bolgherini, Marco Di Giulio, and Andrea Lippi
}

Studies on federalism, regionalism and devolution often tackle the processes of institutional change in a country's polity merely as transitions from an institutional pattern to another, thus mainly focusing on the role of legal frameworks and Constitutional setting in the transition from an equilibrium to another. Such an approach overlooks the role of incremental dynamics: what happens after a new constitutional equilibrium has been reached? Does it stand still, crystallized by formal institutions, or does it evolve in time? This article illustrates the relevance of incremental institutional changes that occur after a major Constitutional reform and shows how an alteration in the distribution of resources among actors may heavily affect the territorial arrangement and the intergovernmental relations (IGRs) of a country. It focuses on the Italian case and the change in its IGRs between 2001 and 2016. Through a secondary analysis, a scrutiny of the trilateral game among the State, the Regions and the Local Authorities - played by reshaping and implementing the initial arrangement through gradual, piecemeal and layered modifications - will be conducted. Evidence is displayed through Dente (1997) resources (legal, political, financial and cognitive) framework. The main finding is that the change in the pattern turns out to be less visible, sometimes ambiguous and sticky, and more uncertain than a change of the pattern, but equally deep and effective. In the conclusion, some interpretative hypotheses for further research on the relevance of change in the pattern and its generalization for multi-level system countries are proposed.

KEY WORDS: intergovernmental relations, games of power, overlapping authority model, negotiation modes, quasi federalism

\begin{abstract}
从模式间转变到模式内转变: 意大利政府间关系的三方博栾
关于联邦制、区域主义和权力下放的学术研究时常将一个国家政体的制度变化过程仅视为一种 制度模式到另一种制度模式的转变, 因此这类研究主要聚焦于法律框架和宪法设置在一种权力 平衡到另一种权力平衡的转变中所扮演的角色。然而, 这种方法忽略了渐进式动态 (incremental dynamics) 的角色:达到一项新的宪政平衡 (constitutional equilibrium) 之后会发生什么?当正式 制度明确其 (定义) 后, 这种平衡是会继续维持, 还是会随时间而不断改变? 本文阐述了重要宪法 改革后渐进式制度变化的相关性，展示了政治行为者间资源分配的改变可能会如何严重影响一 个国家的领土安排和政府间关系 (the intergovernmental relations, IGRs)。本文聚焦于意大利和 该国在 2001-2016 年间的 IGRs 变化。通过第二次分析, 本文将仔细检查州政府、区域政府和 地方政府间的三方博弯，在该博弯中，最初的政府安排被逐步调整，重塑和实施。通过丹特
\end{abstract}


(Dente) 于 1997 年提出的法律、政治、金融和认知资源框架, 呈现了本文结论。主要研究结果 则是, 模式内的转变并非十分可见, 有时还很模糊、难以处理, 这比模式间的转变更不确定。然 而, 这两种转变都一样深入, 一样有效。结论提出了一些诠释性假设, 用于进一步研究模式内转 变的相关性及其对多层系统国家的一般化。

关键词: 政府间关系, 权利博弯, 权威重叠模式, 谈判模式, 准联邦制

\section{Del cambio de patrón al cambio dentro del patrón. El juego trilateral de las relaciones intergubernamentales en Italia}

Los estudios sobre federalismo, regionalismo y descentralización a menudo abordan los procesos de cambio institucional en la política de un país simplemente como transiciones de un patrón institucional a otro, centrándose principalmente en el papel de los marcos jurídicos y del marco constitucional en la transición de un equilibrio a otro. Tal enfoque pasa por alto el papel de la dinámica incremental: ¿qué sucede después de que se ha alcanzado un nuevo equilibrio constitucional? ¿Se detiene, cristalizado por las instituciones formales, o evoluciona en el tiempo? Este artículo ilustra la relevancia de los cambios institucionales incrementales que ocurren después de una importante reforma constitucional y muestra cómo una alteración en la distribución de recursos entre los actores puede afectar en gran medida el ordenamiento territorial y las relaciones intergubernamentales (IGR) de un país. Se enfoca en el caso italiano y el cambio en sus IGR entre 2001 y 2016. A través de un análisis secundario, un escrutinio del juego trilateral entre el Estado, las Regiones y las Autoridades Locales - jugado en el remodelar y implementar el arreglo inicial a través de un proceso de graduales y fragmentarias modificaciones - se llevará a cabo. La evidencia empírica se muestra utilizando el marco teórico de los diferentes tipos de recursos (Dente, 1997): legal, político, financiero y cognitivo. El principal hallazgo es que el cambio en el patrón resulta ser menos visible, a veces ambiguo y pegajoso, y más incierto que un cambio del patrón, pero igualmente profundo y efectivo. En la conclusión, se proponen algunas hipótesis interpretativas para futuras investigaciones sobre la relevancia del cambio en el patrón y para su generalización en los países con sistema multinivel.

PALABRAS CLAVES: relaciones intergubernamentales, juegos de poder, modelo de autoridad superpuesta, modos de negociación, cuasi federalismo

\section{Introduction}

Shifts in territorial patterns at subnational level have been scrutinized by scholars by looking at the change of institutional designs through reforms (Baldersheim and Rose, 2010; Behnke, Petersohn, Fischer-Hotzel \& Heinz, 2011; Benz \& Broschek, 2013; Keating, 2013). Reforms affected both federal states and states with a "multilevel system" (Agranoff, 2014) that experienced devolution, regionalization, or "quasi federalization" (Kuhlmann \& Wollmann, 2014, p. 122) in order to get an improvement in their balance of power, through readjustments and revisions of their intergovernmental relations (IGRs) (Hoffmann-Martinot \& Wollmann, 2006).

As stated by Behnke and Benz (2008, p. 214), reforms frequently concerned a change of the Constitution and often resulted as inefficient and partial. Formal Constitutional amendments seem to be very difficult to achieve and sometimes they trigger further formal and informal (less visible, but incisive) dynamics in the 
vertical distribution of authority that aim at integrating and reshaping the adopted Constitutional change. It means that, beyond explicit and formal amendments, the territorial allocation of power also evolves through secondary, implicit and patchy movements.

In this article, we thus distinguish between the first and the second type of territorial change, and focus on the second one, in order to scrutinize its features and test its significance in studies concerning different territorial patterns and policy change. In the following pages, we call the first type (territorial reforms turning into new arrangements through Constitutional amendments), a case of change of the pattern; and the second type a case of change in the pattern, i.e., territorial reforms concerning limited reorganizations, micro-provisions and de facto realignments that implement the reforms through readjustments in the IGRs and negotiations among the involved tiers of government. It will be argued that the change in the pattern does matter and can significantly influence the implementation of a certain intergovernmental pattern and its development, also by including steps for further reforms.

The first aim of this article is to argue that change in the pattern entails a "game of power" (Scharpf, 1997) among the involved levels of governments as actors aimed at maximizing their power. This game is influenced by contingencies, policy windows, party politics, and legal framework. Second, the article aims at describing what kind of resources may be displayed by each level of government and which negotiations may result from this game.

A case study supports this reasoning: the "trilateral game" among the State, the Regions, and the Local Authorities occurred in Italy from 2001 to 2016, more precisely from the 2001 amendment of the Constitution (approved by popular referendum) and the 2016 attempt (rejected by popular referendum).

Italy is a suitable case for generalizing implications deriving from multilevel system adaptations and for looking inside the change in the pattern of local government and policy change. Italy experienced in fact a long-standing evolution turning in time into an Overlapping Authority Model, according to Wright's (1988) definition of IGRs. Scholars interpreted this layering as a "quasi federalism" (Bobbio, 2005; Brunazzo, 2010; Lippi, 2011): it, in fact, triggered a stepwise trilateral game in vertical arrangement that changed over time into differently shaped center-periphery relations. As scholars described (Baldini \& Baldi, 2014; Bolgherini \& Lippi, 2016), it produced ambiguity and a permanent uncertain oscillation between decentralization and recentralization. All these dynamics have been observed in federalist countries, like Germany, as well as in regionalized (Spain) or decentralized ones (like the United Kingdom) (Behnke et al., 2011). More precisely, while all these countries definitely adopted an intentional arrangement, Italy remained halfway and experienced an Overlapping Authority Model inspired at the same time at federal, regional, and decentralized designs. For this reason, this country may be a case in point to get generalization. The final aim of the article is consequently to show that even if reforms may remain suspended, and thus the rules-in-form may remain the same, the rules-in-use might change significantly. Evidence of how intergovernmental relations change even though the underlying 
legal framework remains the same will be thus provided. The article will analyze the above-mentioned trilateral game by looking at the allocation of policy resources by the State, the Regions, and the Local Authorities according to Dente's (1997) classification. The research question concerns the different allocation of each of these resources and thus the different center-periphery relations during the scrutinized time span. By looking at this different resource allocation over time, it will be assessed the change in the model and the ambiguities of this change. This analysis is set forth in Section 4, while the theoretical background is presented in Section 2 and the Overlapping Model of Authority concerning the Italian case is described in Section 3. Finally, evidence and developments are discussed in Section 5.

\section{Change in the pattern and games of power in the IGRs}

The main topic of this article concerns the institutional change that occurs when a State proceeds toward a more differentiated allocation of power. This process typically concerns federal states (Elazar, 1964), since the key-definition of federalism implies the (constitutionally entrenched and guaranteed) dispersion of authority across many levels of government (Agranoff, 2001). Analogously, the same may be applied to "multilevel systems" (Agranoff, 2014), namely States that experienced a shift from centralistic and monopolistic allocation of authority toward a multilevel vertical arrangement without becoming explicitly federalist (Behnke et al., 2011). Federal states are in fact conceived in the literature as subject to permanent change (Agranoff \& Radin, 2015; Behnke \& Kropp, 2016): their dynamics are considered driven by contingencies (e.g., windows of opportunity, party politics, economic conjuncture, their specific institutional architecture, etc....) (Benz, 2016, p. 724). In federal cases, IGRs may thus result as evolutionary and subject to continuous readjustments. Similarly, also multilevel system can embrace evolutionary change combined to differentiated and layered allocation of power (Benz \& Broschek, 2013).

The basic concern is always the vertical arrangement and the resulting degrees of freedom for each level of government when negotiating power with the other tiers.

Bakvis (2013) showed for instance how in the Canadian case, compared to the EU, the relevance of hierarchy remained inside the level of governments, while in the IGRs it was the mechanism of bargaining to prevail, due to the multilevel and overlapping authority dispersion "in the shadow of (earlier) hierarchy." Equally, Ingold and Pflieger showed the seemingly incoherent attitude of Swiss institutions at international and domestic level, since IGRs matter and shape contradictory policies on the same issue. This point has been extensively analyzed by Wright (1988, pp. 40-48) in his seminal work on IGRs. Adopting a Boolean set description, he argued that IGRs can be shaped on three recurrent models, according to a different extent of flexibility and uncertainty. The first model is called Coordinate Authority Model and assumes distinct boundaries and separate competences between the State and the Local Authorities. In this model, local units can exert only legal power granted by the State, but both entities are independent and autonomous, linked only 
tangentially. Differently, the Inclusive Authority Model entails a hierarchical relation depicted as concentric circles and displays proportional power corresponding to each level. It means that enlargement and reduction of power for one, will imply a proportional widening or diminishing for the others. As in the game theory, one level can win or lose power depending on the others' gains and losses. Finally, both models are superseded from the Overlapping Authority Model (OAM). It combines autonomy and discretion with constraints and influence. While the other two models were opposite - autonomy and independence vs. dependence and hierarchythe OAM mingles interdependency with bargaining. More precisely, it entails six "overlapping features": (1) limited and dispersed power; (2) modest and uncertain areas of autonomy; (3) high degree of interdependence; (4) simultaneous cooperation and competition; (5) negotiation; and (6) agreement by bargaining. All these properties are evolutionary, often implicit and piecemeal. As stated by Wright, OAM is really attractive and successful, since it permits both ambiguity and degrees of freedom along with routinization by practice. Somehow OAM implies an undefined, but permanent, re-arrangement among level of governments. For these reasons, it seems particularly suitable for analyzing contemporary networked patterns of government and multilevel governance (Agranoff \& Radin, 2015; see also Ingold \& Pflieger, 2016; Fraune \& Knodt, 2017).

On this point, Alcantara, Broschek and Nelles (2016) specified the difference between Multi Level Governance (MLG) and IGRs. MLG broadly involves multilevel systems together with a variety of nongovernmental actors organized at different territorial scales and aimed at producing public goods. IGRs include instead the relationships between level of governments producing public goods in the same country limited to the institutional vertical chain. Consequently, IGRs "are a discrete instance of multilevel politics in which government actors engage primarily with other government actors, organized at the same territorial scales, in a process of decision making" (Alcatara et al., p. 42). According to Agranoff (2014, p. 3), IGRs may be defined as the various combinations of interdependencies and influences among public officials in all types and level of governmental units with particular emphasis on financial, policy, and politics issues. Analogously, Kuhlmann and Wollmann (2014, pp. 119-121) stress the unstable and changeable geometry between center and periphery and its upwards or downwards adaptations as the main IGRs' feature.

Nonetheless, whenever treating with IGRs, we cope with a certain amount of negotiation concerning the overlapping power formally assigned to different levels of government. Certainly, the institutional arrangement matters and can determine the type and the intensity of bargaining. As stated by Benz and Broschek (2013) and by Benz (2016), Constitutional change represents the starting point for this reasoning. Games of power resulting from the OAM can take place if, and only if, territorial arrangement has been formally and previously modified through a change of the Constitution that assigned a different allocation of authority across national territory - for instance, from unitary to regionalized State, or from regionalized State to a cooperative federalism. This is a change of the pattern. The rise of meso-government through the empowerment of the regions (Sharpe, 1993) or the rescaling strategies of the Nation-State (Keating, 2013) are both examples for change of the pattern. 
The micro-adjustments (including decentralization or de-concentration) are a second type of change and concern instead the stepwise bargaining and redefinition of competences, authority, and policies between the center and the periphery (for instance, from cooperative to coercive or polarized federalism). This is thus a change in the pattern and it is intrinsic to multilevel systems.

Therefore, Behnke and Benz (2008, pp. 216-217) distinguish between reforms (i.e., the change of the pattern) and evolution (i.e., the change in the pattern). While reforms are explicit and defined as an alteration of the written text of the Constitution by amendments, evolution is often implicit and formally residual and affects constitutional change that does not pertain to the written text, "altering meaning and practices without changing the wording" (Behnke \& Benz, 2008, pp. 216-217). Behnke and Benz argue that implicit change necessarily occurs because Constitutions are incomplete contracts and never definitively delimit neither the powers assigned to each actor and institution, nor the scope of the decision rules. The implicit change can additionally stabilize and legitimize the state arrangement through de facto micro-alterations, specific and limited legislation, intergovernmental agreements or even judicial sentencing (innovative interpretation). Evolution is instead more hidden and creeping, but incisive and often leading to (further) potential change of the Constitution. It may occur between two reforms and may match rules, informal practices, legal interpretation, and political agreement among political parties. Moreover, evolution deals with a routinization of the new pattern in a relatively modified arrangement. This change fits the gradual institutionalist perspective (Mahoney \& Thelen, 2010): it is not an official change, but a "gradual and layered" one "without a clear direction" (Benz, 2016, p. 712).

In this perspective, a change in the pattern may consequently include negotiation modes. These modes may determine the type of relationships among levels. This concept has been introduced by Petersohn, Behnke and Thode (2015) in a comparison of multilevel systems looking at the permanent reallocation of power in state-society relations due to contextual factors and party politics. Negotiations have been also singled out by Dente (1997) in five types of resources available to each level of government: legal, financial, political, information, and know-how resources. Legal resources comprise the formal division of powers enshrined in the Constitution and laws; financial resources mean the possibility to collect and spend money and the control over these movements; political resources include the channels of access and influence both from the part of single politicians and political parties; information resources mainly concern data collection for policymaking; and know-how resources include the technical skills of the bureaucratic apparatus. In this article, information and know-how resources will be grouped together and considered as cognitive resources.

Within these negotiations, the role of parties is reputed as crucial: the centerperiphery cleavage shapes parties' organization and representation, and this fact influences, in its turn, both strategies and political relevance of negotiation (Hopkin, 2003; Thorlakson, 2009). Moreover, devolution and decentralization may influence parties' adaptation in national arenas and in the creation of 
opportunities at the local level, as well as in the maximization of their power through the IGRs (Van Biezen \& Hopkin, 2015).

Negotiation modes can be thus classified by looking at two dimensions: the horizontal and the vertical one (Petersohn et al., 2015). The vertical one simply concerns the degree of decentralization assigning autonomy or self-rule to substate governments by power transfer (and reverse). Horizontal dimension concerns asymmetry in power distribution among territorial units. Both dimensions may open to different negotiation modes: (1) unilateral, involving only actor at the center; (2) bilateral, conducted between the center and one substate entity; and (3) multilateral among the center and the representatives of one or more substate entity at the same time. Multilateral negotiations are more oblique and uncertain, because they require consensus among diverging interests. Wallner (2017, p. 420) states that the set of negotiating relations may occur as combination of three $C^{\prime}$ s: coercion, competition, and cooperation. They are not alternative but complementary, and can be exerted either from above or from below according to contingencies and to social, political, and financial factors. Following this perspective, Agranoff (2014, p. 7) states that multilateral games are the essence of IGRs, while Benz (2016, p. 716) argues that the interplay among levels of government is made of political negotiation, administrative policy-making and the interpreted and preserved law by the Constitutional Courts. In this case, IGRs can consequently be understood as "sequential of games" played by levels of government as political actors (Behnke and Kropp, 2016, p. 587).

This last aspect has been deeply scrutinized in studies on federalism. Posner (2007) pointed out the coercive federalism played by different administration in the United States favored centralization and supervision. Previously, Kincaid (1990) observed the pendulum from cooperative to competitive American federalism by analyzing the bargaining between States and the Federal administration. More recently, Conlan (2017) described the move from cooperative to polarized federalism emerging from changeable interpretation of IGRs in Canada. Lastly, Biela, Henni and Zons (2014) focused on Swiss federal strategies to overcome deadlocks by empowering substate entities not at the decision level, but at the implementation level: by granting more decentralization to substate levels may preserve their leadership and favor autonomy.

As for nonfederal cases, Sandford (2016) scrutinized the British case and interpreted devolution not as a territorial governance evolution, but as a series of contract-style agreements between central government and local public bodies to pursue agreed outcomes in certain policy areas. He claims that a post-territorial governance is taking place as a result of the role playing by both center and periphery.

All these examples refer to changes in the pattern, and not of the pattern. As theorized by Elazar (1964), subnational governments are not agents of some national government hierarchy, but important players in the intergovernmental system. Interplay can consequently embrace collaboration, but also ambiguity and hypocrisy (Agranoff, 2001). Moreover, this interplay produces variable outcomes, which may result not necessarily coherent, but often incremental and 
contradictory. Nonetheless, these "suboptimal" outcomes may smooth divergences and contribute to integrate disparities and to prevent conflicts.

Evolution (change in the pattern) can consequently be observed as stepwise sequence of disentanglement and re-entanglement. This effect seems fitting to the Lindblom concept of disjointed incrementalism relaunched by Hoppe (2017, p. 228). Change in the pattern can be consequently intended as a type of incoherent and piecemeal muddling through adjustments.

Kropp and Behnke (2016) depict the zigzagging trajectory of German federalism looking at incongruity intrinsic to the game of power when Constitutional change is implemented and every change may lead to a new reform that postulates opposite goals. This institutional incongruity is typical of the change in the model, since it displays the incremental attempt to make reforms effective both in the light of societal and economic needs, and of political pressures by the parties. The overall result is a sticky, layered and never clear and definitive change.

Summing up, three points may result from this theoretical review. First, a change in the pattern is an incisive trend of informal and formal interventions that may significantly alter the territorial arrangement according to the resources available to each level of government. As such, it represents a gradual, layered, and unclear adaptation of the "official" reform, indirectly contributing to consolidate or reshape institutional change. Second, this evolutionary change is not mechanic, nor linear, but similar to a game of power played by the different levels of government acting as political actors. Third, the result is a sticky change, often contradictory and without a clear direction: a definitely ambiguous and layered change.

\section{The Italian case: trilateral game and change in the quasi-federalist pattern}

\section{The overlapping authority model after the 2001 reform}

Against this background, the Italian case provides an excellent viewpoint on these topics. Italy experienced three major attempts of Constitutional change (along with a series of minor changes throughout the decades) in the last 20 years (Vandelli, 2012). The year 2001 marked the shift from a unitary to an OAM, recently interpreted as a case of quasi-federalism (Brunazzo, 2009; Lippi, 2011). Then, a devolution reform aiming at reinforcing the regional competences on some matters failed in 2005 and an overall reform aiming instead at overhauling the whole political and institutional system failed again in 2016. The 15-year time span between the first (2001) and the last attempt (2016) will be here taken into consideration with a focus since 2010, in order to investigate the impact of the change in the pattern in the Italian state and the dynamics of what may be labeled trilateral game, that is a game of power played by the State, the Regions, and the Local Authorities in those years.

Throughout the 19th century, the Italian State had been established as unitary following the French Napoleonic model (Kuhlmann \& Wollmann, 2014, pp. 57-59). This unitary arrangement was maintained also after World War II with the Municipalities and the Provinces (the 2nd tier) entirely subdued to State authority (Baldini 
\& Baldi, 2014; Bolgherini \& Lippi, 2016). This arrangement changed in 1970, when the Italian Parliament approved the final implementation of 15 ordinary status regions (OSRs) in addition to the five special status regions (SSRs) already established in the aftermath of World War II. During the 1970s and the 1980s, the State was still in charge to steer the local affairs but it was supported by the local branches of national parties (Tarrow, 1977), while since the early 1990s local authorities were strongly empowered (Bobbio, 2005). The direct elections of mayors and provincial presidents in 1993 and that of regional presidents in 1999 paved the way to reinforced meso- and local levels of powers and to the 2001 reform.

The Constitutional reform approved in 2001 devolved to the Regions a series of State powers ranging from environmental planning, energy, transportation, etc. and heavy-budget tasks (i.e., health policy), thus resulting in an OAM. Nonetheless, the Regions partially disregarded these new intergovernmental tasks (Piattoni \& Brunazzo, 2010) and an intentional attitude of regional steering and governance was promoted only by a limited number of Regions: hence, the overall regional capacity to steer local governments and territorial governance remained weak. In those same years, the State lost capacity of control on both the Regions and the Local Authorities while its strongest tool still remained its transfers toward the other levels of government. As for the Local authorities, municipalities in particular experienced an increase in terms of legitimacy but they increasingly accumulated public debt and lost some of the freedom gained in the previous decades (Bolgherini, 2016; Dente, 2012). The failed devolution reform in 2005 signed a turning point but reinforced these trends and thus the overlapping authority model, with all its ambiguities. All these evolutions led in time to the most recent changes of the trilateral game and to the last turning point of the Italian change in the pattern, started since 2010 (Bolgherini \& Lippi, 2016) (see Table 1).

In 2010, due to the global crisis, the national center-right coalition government led by Silvio Berlusconi started to enact some austerity measures, which were later implemented and pursued also by the following three governments led by Mario Monti, Enrico Letta, and Matteo Renzi, respectively. Triggered also by exogenous constraints such as the EU pacts (Dinan, 2012; Dyson, 2012), the austerity measures were all oriented to balanced budget, public expenditure containment, and cost saving. That translated mostly into cuts of state transfers to local governments and in an increasing limitation of local autonomy (Bolgherini, 2014, 2016).

Austerity represented a policy window for the central level to pursue a new strategy consisting in the progressive erosion of previously existing arrangements. Differently from the past, the goal of this reshaping strategy was the rescaling of the whole system through "a stronger coordination and steering role of the central state to the detriment of the local levels" (Bolgherini \& Lippi, 2016). Such a rescaling intention mostly revealed itself in the law (No. 56/2014) known as the Delrio Law, approved in 2014 and which fixed a minimum threshold of institutional change to be fulfilled by local authorities, and delegated the Regions to further implement their internal multilevel governance with 
Table 1. Evolutionary Overlapping Authority Model in Italy 2001-2016

Year and event
2001 Constitutional reform
on Title V ratified by
referendum (Const. Law
3/2001)

2003 (L 131/2003-La Loggia)

2005 Constitutional reform proposal on Devolution 2006 referendum on Devolution Const. reform 2009 Fiscal federalismrevision of art. 119 Const. (L 42/2009)

\section{Urgent measures} concerning regional and local authorities (DL 2/ 2010 then converted into L 42/2010)

2011 austerity measures (DL 138/2011 Summer measures and DL 201/2011 Rescue Italy)

2012 Spending review (DL 95/2012 - spending review -then modified and converted into L 135/2012) 2013 National budget law for 2013 (L 228/2012 Stability law)

2014 Delrio Law (L 56/ 2014)

2016 Constitutional reform proposal

Content

Political turning point

Federalist shift: attribution of legal exclusive power to the regions (by enumerating, in art. 117, the state's exclusive legislative powers and leaving all the rest to the regions); explicit statement for subnational authorities of a constitutionally guaranteed status as constituent parts of the Republic

Partial implementation of the 2001 constitutional reform: Federalist attribution of powers to the regions

Devolution (arts 117-118); Federal Senate

Const. reform on devolution rejected through popular referendum

Settlement of fiscal federalism principles (correspondence between local revenues and available financial resources at the same local level; autonomy, responsibility, coordination, cohesion, and solidarity)

Suppression of territorial areas authorities (ATOs); cutbacks to state transfers to local bodies

Further measures for financial stabilization and development and Urgent measures for growth, equity and public finance consolidation: Suppression of provinces (aborted); provisions on IMC and cooperation among small municipalities;

Reduction of province functions; provincial executive body suppressed; indirect election of provincial president

Urgent measures for spending review with unaltered services for citizens

Measures for metropolitan cities, provinces, municipal unions and fusions

Suspension of metropolitan cities and province merging

Reallocation of power among substate levels: Weakening of the provinces, implementation of the Metropolitan cities, empowerment of IMC and Municipal Unions and amalgamations

Constitutional reform proposal

Const. reform rejected through popular referendum
Center-left government tries to smooth down Northern League claims for federalism and "secession"

Northern League in the governing coalition

Bridge period between decentralization and recentralization trend

Global crisis and austerity paradigm Technocratic government (Mario Monti)

Legislative elections: political stalemate

Matteo Renzi's government: attempts to a change the pattern 
a high degree of autonomy, even if under relatively strict time constraints (Bolgherini 2015; Bolgherini, Lippi \& Maset, 2016; Di Giulio and Profeti, 2016). This law should pave the way to the major Constitutional reform of 2016, which should have replaced the Senate with a Chamber of the regions, entitle regions and municipalities with further tasks, eliminate the provinces and other multilevel arrangements. Approved in Spring 2016, this reform was rejected by a popular referendum in December of the same year. Nonetheless, the Delrio law is fully operational and it is producing effects on the trilateral game as well as changes in the pattern.

Table 1 displays the main innovations occurring in 2001-2014 leading to the main changes in the pattern in the Italian case.

\section{Research design and questions}

The change in the pattern, scrutinized in the Italian case, has an empirical and a scientific relevance (Gerring, 2007). First, for the scope of this change and for its systemic effects, and thus for its empirical evidence. Second, for the fact that Italy may be a potential case for all those countries experiencing multilevel system and moving through partial adjustments, by showing that a change in the pattern may be as impacting as a change of the pattern. In this regard, the Italian case provides in fact incisive insights for other cases where institutional or policy deadlocks have become relevant only recently. The paper sheds light on a dimension of change that is often overlooked in political science and that is likely to become crucial across Europe. The research question that guided our analysis was in fact to explore the ambiguous and minor-but enduring and lasting - adjustments in the Italian pattern in order to assess if and how those changes affected the trilateral game among the State, the regions, and the local authorities. The blurred pattern that Italy displays is in fact not an atypical one. Other countries in Europe (e.g., Germany, Spain, UK) show, although differentiated, evidence of change and more or less visible shifts are detectable. The Italian case may thus provide an interesting asset for cross-country comparisons. Thirdly, as it will be hinted in the conclusion, for this type of change may turn out to be a sort of conflict-smoother and a system-stabilizer, by preventing strong(er) contentious attitudes among the three players of the game.

The trilateral (State-regions-local authorities) game and the relevant negotiations and exchanges will be scrutinized under the lens of the actor-centered approach (Scharpf, 1997), thus considering each level of government as an actor playing in the game and having interests and resources at stake. The portrait of the change in the pattern in the Italian case will be provided by analyzing the different resources in the hands of each of the three players in the trilateral game, according to the types of resources proposed by Dente (1997) and recalled in the previous section.

As mentioned in the Introduction, the main goal of this article is to understand the allocation of resources and to assess the different center-periphery relations during time in the model and the ambiguities of this change. A secondary 
analysis, mostly based on previous researches and on documental materials, will be thus carried out. In the following section, the relevant empirical evidence gathered in this analysis will be provided.

\section{Change in the model: resources of the trilateral game}

This section assesses the main movements occurred to IGRs in Italy since the 2001 reform. The assessment does not take into consideration all adjustments that have occurred in such a time span - such as, just to name a few, the restructuring of functional authorities regulating public services, the measures concerning taxsharing agreements, the power to collect taxes for LAs, the so-called federalismo demaniale (the possibility for LAs to utilize and valorize real estate properties of the State concerning cultural and natural heritage). Conversely, the assessment focuses on some major adjustments occurred that significantly contributed to reshape IGRs in Italy. Such changes mostly took place since 2010, as the financial crisis eventually forced the Italian national government to implement austerity measures. These, in turn, paved the way for a new wave of institutional reforms ended up with the Delrio Law in 2014.

Table 2 summarizes how these major adjustments have only occurred in certain domains, while substantial stability has marked other domains.

\section{State-regions}

After the 2001 Constitutional Reform, the relation between the State and the Regions used to be significantly conflictual (Baldi \& Tronconi, 2011). That was mostly due to the ambiguous allocation of legal resources between the two levels in the concurrent law-making competences. Although in terms of legal framework, the relations among the two actors have remained quite stable, even after the Delrio reform, State and Regions have struggled over its implementation. The number of Court litigations between State and Regions is emblematic in stressing this situation (Lippi, 2011): legal contentious between State and the Regions after the 2001 Constitutional reform has involved great part of the Constitutional Court activity with more than 1,500 trials started from 2003 to 2015. The peak of this

Table 2. Resources in the Trilateral Game (2010-2016)

\begin{tabular}{|c|c|c|c|c|}
\hline Game/resource & Political & Legal & Financial & Cognitive \\
\hline State-regions & $\begin{array}{l}\text { Empowerment } \\
\text { of Regions' } \\
\text { Governments }\end{array}$ & Stability & $\begin{array}{l}\text { Same autonomy } \\
\text { Shrinking resources } \\
\text { since } 2010\end{array}$ & $\begin{array}{l}\text { Incremental } \\
\text { empowerment of } \\
\text { Regional resources }\end{array}$ \\
\hline State-LGs & $\begin{array}{l}\text { Empowerment } \\
\text { of grass } \\
\text { roots political } \\
\text { class }\end{array}$ & $\begin{array}{l}\text { Formal } \\
\text { stability with } \\
\text { destabilizing } \\
\text { micro-regulation }\end{array}$ & $\begin{array}{l}\text { Increasing LGs fiscal } \\
\text { autonomy until } 2010 . \\
\text { Politicization } \\
\text { and uncertainty } \\
\text { since } 2011 .\end{array}$ & $\begin{array}{l}\text { Incremental } \\
\text { empowerment of } \\
\text { LGs resources }\end{array}$ \\
\hline Regions-LGs & $\begin{array}{l}\text { Context-specific } \\
\text { balance of power }\end{array}$ & $\begin{array}{l}\text { Expansion } \\
\text { of Regions' } \\
\text { competences }\end{array}$ & Stability & Context-specific \\
\hline
\end{tabular}


trend occurred in the first years of the global financial crisis (2008-2011), while since 2013 the total number of Court litigations slowly decreased, probably due to the expected new Constitutional reform process. The 2016 Constitutional change should remarkably alter State-Regions relations in its legal dimension. According to this reform (Law n. 387/2016), Regions should appoint their representatives in the new Senate. A significant range of tasks about decentralization and local policies should consequently be shifted to the new Senate, especially those concerning impact evaluation and EU policies: at least on paper, the new Constitution should strongly empower Regions' political resources. Its failure did not keep the status quo entirely due to the operating Delrio Law, which points in the same direction of the aborted Constitutional reform. The long-established Conferenza StatoRegioni-a permanent coordination venue with representative of national and regional governments - never institutionalized as a real political arena for bargaining between the Regions and the State (if excluding its complaining about financial transfer and the quest for additional funding from the State (Tubertini, 2010). The conflict on legal resources can be thus interpreted as a byproduct of a change in the distribution of political resources between State and the regional governments. These latter are in fact emerging as new political centers, due to the empowerment of Regional Presidents (Musella, 2009) — who often undertake symbolic political conflicts with the State over high salience issues-and to the structuring of political parties at regional level (Ignazi \& Pizzimenti, 2014). As far as the preference of national parties are concerned, the issue of empowering regionalism has been a constant feature of the center-left Democratic Party (Partito Democratico-PD)'s strategies, while the right-wing regionalist-born Northern League (Lega Nord) has maintained - to some extent paradoxically-a more prudent profile due to a more localist bias (Di Giulio and Profeti 2016).

A pattern of stability emerges as far as financial resources are considered. Although the Italian quasi-federalism has recently gained momentum - in terms of political power devolved to Regions - still the meso-level government has limited fiscal powers and the OECD Tax Database keeps considering Italy among unitary countries with no significant tax revenues collected at the regional level (Table 3). A closer look to regional accounts gives a more nuanced picture of regions' fiscal autonomy, which highlights a high rigidity of both revenues and expenditures. On the one hand, fiscal autonomy is not irrelevant: in fact, despite the total amount of regional tax revenues is limited if compared with more advanced federalist political systems, revenues from taxes, sales, capital gains (entrate tributarie ed extratributarie) rose on average from 57 to $66 \%$ between 2007 and 2013 (ISTAT 2014), with remarkable regional divergence. Besides, it is worth noticing that Italian regions do not have their own taxes, but they mostly rely on tax sharing agreements by which they benefit from some percentage of national taxes. The great part of regional tax revenues come from the Regional Tax on Corporate Income, which is a tax on companies' incomes and from variable amounts of the income tax and the VAT. However, Regions cannot dispose of these revenues at their own will, since these revenues cover almost the $88 \%$ (in 2014) of the National Health Fund (Corte dei Conti 2016, p. xv). Since 1993, the national 
health system has been in fact regionalized as regional governments took over powers both from the State and local authorities in a sector that nowadays accounts alone for almost the $80 \%$ of their current expenses, and represents the $16 \%$ of the overall Italian public expenditure (Corte dei Conti 2016, p. xvi; Toth, 2014, p. 7).

The scenario concerning cognitive resources displays an incremental empowerment of Regions - even if scattered along the North/South and big cities/small municipalities divides. Since the 1990s, Italian Regions increasingly equipped themselves with agencies and managerial skills. The State delegated the Regions to establish targeted agencies for environment (e.g., river basins), job placement, tourism, public utilities (water and sanitation, waste and disposal, local transportation). Many Regions autonomously promoted the creation of specialized agencies to manage specific policy sectors (e.g., economic development, research and consulting, agriculture, ICT and digital divide, NGOs). Almost all Italian regions hold financial and trade consulting agencies. All these entities can be gathered into holding: for instance, the Region Lombardy created the "Lombardy system", a network of agencies integrating four strategic sectors of activities: ICT, infrastructure, furniture, and grants. Lastly, the regions may own public-private companies or public companies operating in limited, but territorially relevant (in some case also very profitable), fields of activities, such as buildings, cinema industry, theatre and arts, transportation and highways, trade shows and exhibition, thermal baths, parks and biomedicine, etc. (Citroni, Lippi \& Profeti, 2015b). As far as the managerial skills are concerned, the landscape is even more scattered and irregular across the country. Italian Regions historically hire managers which are more highly educated than those in the remaining public sector. Nonetheless, scholars repute their overall number to be unsatisfactory (Capano \& Vassallo, 2003): in 2013, the $38 \%$ of managers had a master's degree, but in general the population of managers is aged (aged 55 on average) and careers are really long (a manager achieves its/her position on average after 30 years as public employee (Vassallo, 2015). As for civil servants in general, the five SSRs have more personnel $(92,000)$ than the 15 OSRs. Some regions created specific expert staffs supporting the governors and the general managers, while others displaced their managerial positions throughout the bureaucratic structure.

\section{State-Local authorities}

Also in the case of State-Local Authorities (LAs) relations, the legal resource framework experienced no radical changes over the last 15 years. The only major issue is represented by the progressive de-institutionalization of Provinces, which have been transformed in non-directly elected bodies whose executives are appointed by municipalities. Such a transformation, nonetheless, hardly represents a downsizing of LAs' legal resources. In fact, since long Provinces have become "colonies" of the municipal political class, so their transformation is only the ratification of a gradual change with no significant impact in term of legal allocation of resources. 
Conversely, as far as political resources are concerned, local politics surely expanded its influence in the national arena. In the last decades, Italian mayors achieved increasing influence and prestige in the country's politics: mass media often interview them on national issues and their opinions are reputed relevant by anchor-men and the public opinion. This strongly overemphasized the real expertise and the leadership of Italian mayors, but it is a fact they are considered as the "healthy" part of Italian politics (Bull \& Rhodes, 2007; Diamanti, 2003). ${ }^{1}$ Such a rising influence of local political class has instead gained the center of the stage during the formulation of the Delrio reform (Di Giulio and Profeti, 2016). In this phase, in fact, the core government positions have been filled by former local politicians. It is worth noticing that the political leadership at the national level during the Letta's and (even more impressively) Renzi's cabinets, dramatically changed its nature: national governments have been formed mainly by grassroots, locally grown politician. Significantly, Graziano Delrio was previously President of ANCI (the Association of Italian Municipalities), while Matteo Renzi was the mayor of Florence. Also within the Democratic Party, prominent officers in this period were mayors, like Piero Fassino, who has been involved in the abovementioned decisional processes as ANCI president and mayor of Turin.

The rise of local political class has been underpinned also by a trend of increasing fiscal autonomy for LAs. As highlighted in Table 3 above, over almost forty years, Italy became one of the countries where LAs have the most pronounced autonomy after having been one of the least decentralized. Hence, increasing LAs' tax powers has been one of the priorities for the reforms implemented in the early 1990s. The introduction of a Tax on Buildings (ICI) effectively produced an abrupt increase in LAs' autonomy that nonetheless is not equally distributed throughout the territory: been dependent on the real estate values, LAs' fiscal system has undermined the revenues of less developed areas (Ambrosanio, Balduzzi \& Bordignon, 2015). Besides, over the last decade Italian LAs' fiscal autonomy has faced a troublesome and to some extent paradoxical evolution. Political parties - and prominently the Northern League-have in fact strongly advocated for fiscal federalism, surrounded by a public debate largely in tune with this decentralizing programme. The shared belief was that the more the financial resources available at the local level, the higher the accountability and effectiveness of its local political class (Bordignon, Galamerio \& Turati, 2014).

Table 3. Tax revenues of subsectors of general government as $\%$ of total tax revenue

\begin{tabular}{|c|c|c|c|c|c|c|c|c|c|c|c|c|}
\hline & \multicolumn{3}{|c|}{ Central government } & \multicolumn{3}{|c|}{$\begin{array}{c}\text { State or regional } \\
\text { government }\end{array}$} & \multicolumn{3}{|c|}{ Local government } & \multicolumn{3}{|c|}{ Social security Funds } \\
\hline & 1975 & 1995 & 2014 & 1975 & 1995 & 2014 & 1975 & 1995 & 2014 & 1975 & 1995 & 2014 \\
\hline Germany & 33.5 & 31.4 & 31.2 & 22.3 & 21.6 & 22.0 & 9.0 & 7.4 & 8.2 & 34.0 & 39.0 & 38.1 \\
\hline Spain & 48.2 & 50.4 & 42.3 &.. & 4.8 & 13.6 & 4.3 & 8.5 & 10.0 & 47.5 & 35.8 & 33.6 \\
\hline France & 51.2 & 42.3 & 33.1 & .. &.. &.. & 7.6 & 11.0 & 13.0 & 40.6 & 46.3 & 53.7 \\
\hline Italy & 53.2 & 62.7 & 53.4 & .. & .. & .. & 0.9 & 5.4 & 16.5 & 45.9 & 31.5 & 29.8 \\
\hline UK & 70.5 & 77.5 & 75.8 & .. & .. & .. & 11.1 & 3.7 & 5.0 & 17.5 & 17.8 & 18.7 \\
\hline
\end{tabular}

Source: OECD, Fiscal Decentralization Database (2015). 
Nonetheless, substantial policymaking has largely neglected this federalizing commitment, and local taxes' cuts have instead become a contentious issue for national electoral campaigns (Bussu \& Galanti, 2015). In 2007, the center-left government led by Romano Prodi operated a first and limited cut on ICI for lower income households. This paved the way for a very divisive political campaign in 2008, which led Silvio Berlusconi's center-right government to completely abolish ICI. That explains the dramatic curb of local taxes revenues occurred in 2008 (Table 3). Later on, the technocratic executive led by Mario Monti reintroduced a tax on buildings (now called IMU), which revenues were only partially collected by municipalities - while roughly half of the income goes to the State in order to cope with the financial crisis. Recently, the Renzi government decided to politicize local tax issue and abolished IMU tax in the budget law for 2016, covering municipalities losses with inter-governmental transfers.

In terms of cognitive resource, LAs seem to have gradually expanded their capabilities. Experts and well-trained practitioners have traditionally been the main resources of municipalities since the 1970s. In the last decades, however, Italian municipal management reinforced even more their cognitive tools: on the one side, through new and well-trained local managers, on the other side through the development of training experiences and meeting activities among local public officers. This fact contributed to show a public image of local civil servants strikingly opposed to that of State public employees (Santoro, 2014). Scholars interpreted this process as an effect of the strong commitment of the local civil servants in the performance of municipal policies. That because they are mostly recruited at local level and work for the administration of the municipality they live in. The cognitive empowerment prominently consisted in acquiring NPMoriented new expertise (human relations, accounting, evaluation, etc....) replacing the mere traditional legal background, and in fostering the capacities to create networks, communities of practices and associations among the municipalities and their public employees (Lippi, 2003). This growing trend drastically slowed down in the last decade, in particular after the global economic crisis. Austerity policies dramatically retrenched funds for training and networking, although the diffusion of new expertise and practices at local level still remains a relevant resource for municipalities. Moreover, in the last years, the National Association of Italian Municipalities (ANCI) increasingly equipped with archives and databases, as well as with consultants and agencies, which support the Association in its advocating policies toward the State. As a result, the Ministry of interior's State archives on municipalities has been integrated by those of research and consultancy agencies on local financing (IFEL) and local policies (CITTALIA), directly managed by the associations of municipalities.

\section{Regions-LAs}

Since 2001 and until recently, the relations among Regions and LAs have undergone only little change, with regional governments still having few powers at hand to shape their own territorial governance. The Delrio Law altered such 
equilibrium through the de-institutionalization of the provincial governments, the effective implementation of the Metropolitan cities and by setting a comprehensive framework for municipal unions and amalgamations. As said, this law was intended to integrate a constitutional change, which instead eventually failed. Nonetheless, the Delrio provision is effective and has started to produce transformations.

In terms of legal resources, Italian Regions have acquired for the first time a clear mandate to reshape their own territorial governance according to their own specific strategies. The implementation of this political opportunity has nonetheless, until now, been scattered and slow. If, on the one side, such a change may be considered as a zero-sum-game won by the Regions, on the other side, the impact of this change turned out to be very different throughout the country as the specific distribution of political local resources within each region could counterbalance the new authoritative powers of regions: only in some specific cases, the OSRs adopted a clear and intentional pattern of subregional governance. Most of them have instead been inertial and have waited for the approval of the Constitutional reform to take a path in this respect. Court litigations and strong political cleavages between political parties and different subregional areas also hindered the implementation process. To provide a portrait of this in fieri situation, three main regional strategies can be singled out: (1) a hard neocentralist strategy, supported by those Regions (e.g., Tuscany) that explicitly absorbed their provinces' legal tasks; (2) a soft neocentralist strategy enacted by those Regions (e.g., Emilia-Romagna and Lazio) that instead adopted a multilevel governance approach, which allowed them to preserve their provinces but strongly strengthened the regional steering and coordination power; (3) a maintaining strategy, supported by those Regions (e.g., Lombardy), which decided to preserve the previous arrangement and thus enacted only a limited reshaping of the provinces and empowered their municipalities (Bolgherini et al., 2016). Be it as it may, the new subregional governance, in particular the creation of supra-municipal areas, has been promoted by some Regions with the aim of creating an intermediation with the municipalities. That triggered a sort of domino effect: municipalities and provinces excluded from the new metropolitan cities quested for new functional areas (Area vasta) or for enlarged metropolitan cities, which should include them. By doing so, territorial governance in each Region reshaped, in an action/reaction dynamics, the initial design conceived by each regional government: the original design triggered in fact a quest for adjustments and redesign at the local level. This process of re-definition of borders and authorities (especially of the Aree vaste) has not ended yet and has thus far displayed, as said, very different results in the Italian Regions. Another policy area where Regions acquired legal powers is that of municipal amalgamation. Voluntary amalgamations were introduced in 1990 and never converted into compulsory ones. Their total number has been very limited until 2010 (Baldi \& Xilo, 2012): only nine mergers took place in that period. Municipal amalgamations have been enhanced by the devolution in 2001 and then by the fiscal constraints after the economic crisis, when they became an important tool to try to reduce public expenditures. Their total number increased when the Regions were delegated by the Delrio law to steer their subregional governance strategy 
(Marinuzzi \& Tortorella, 2014): from 2014 to 2016, 50 new amalgamations have been recorded. They mostly appeared in Center-North regions (i.e., Emilia Romagna, Trentino, Lombardy, and Tuscany) and include also municipalities with more than 5,000 inhabitants. These mergers have been strongly fostered by State financial contribution $(+20 \%$ of financial transfers every year for 10 years and the dispensation out of the restrictions of the Stability pact for 3 years). Many Regions additionally promoted amalgamations with own financial support and benefits, with targeted campaigns and deliberative democracy strategies. The amalgamation figures are still limited but evidently growing (Bolgherini, Casula \& Marotta, 2017; Mauri \& Ricciardi, 2015; Rumpianesi, 2014) and increased where the Regions engaged politically beyond the State legal framework, and thus promoted additional incentives and exhibited political and symbolic commitment through advertising, deliberative democracy procedures, etc.

As far as financial resources are concerned, the Regions-LAs relation has traditionally little salience and faced little change. No specific financial transfer from the Regions in favor of Local authorities is worth noticing, even with the recent IGRs arrangement. Regions can provide funds to support local policies, in particular by incentives and funds provided by specific regional laws on certain topics or policy areas (e.g., amalgamations, local transportation, social services, health, etc.) or by competitive announcement for grants, mainly provided by European funds on specific activities.

\section{Discussion and conclusion}

The article focused on the long-standing territorial arrangements in Italy scrutinized as a multilateral game among three different levels of government (State, Regions, and Local Authorities) from 2001 to 2016, namely after shifting away from the unitary State model through the devolution of power and autonomy to substate entities. In the considered 15-year time span, a stream of legal provisions, financial deployment, parties' strategies and informal practices followed the Constitutional reform held in 2001 and marked a long phase of minor adjustments and enduring changes. A gradual, stepwise and partially contradictory incremental change, without any specific direction, brought Italy away from the unitary pattern and shifted it through continuous readjustments toward a more mixed and undetermined arrangement. As a result, IGRs moved either toward decentralization or instead toward recentralization, according to specific provisions and policy windows that, each time according to the relevant political situations, favored such adaptations.

Relying on the empirical evidence of the trilateral game presented in the previous section and based on the type of resources in the hands of each of the three territorial actors, the evolution of Italian IGRs may be summed up as follows.

The State/Regions game entitled the regions with the task of steering and shaping the subregional governance according to their local policy priorities, visions, and responsibilities. Their political resources increased as well as their cognitive ones. Although they gained power during time, they still need(ed) both 
popular support and strong public transfer by the State to finance their public spending in crucial policies like healthcare. Furthermore, the national State repeatedly attempted, in recent years, to downsize them by using the financial policy instrument. The institutional body entitled to coordinate State-Regions relations (the Conferenza Stato-Regioni) is both undervalued and marginal. On the contrary, the role of parties emerged as crucial to mediate the IGRs: regional governors increasingly aim(ed) at influencing the national political system, while national parties tend to limit the political salience of the Regions. Currently, the future of State-Regions relations is extremely provisional, also due to the failed 2016 constitutional reforms and the incomplete landscape it consequently left (in particular the Delrio law, which now suffers the lack of those parts of the constitutional reform that should have completed it). It is hence probable that the Constitutional Court will continue playing a major role on this side of the trilateral game.

The State/Local Government relations saw LAs being financially constrained through the austerity measures and through a harsh strategy of cutbacks of public expenditure, fiscal retrenchment of public services and organizational consolidation. Moreover, a significant and creeping recentralization affected the Local Governments since 2008 in favor of the central State and to the detriment of their own autonomy. The legal resources remain formally relatively stable, even if an intense micro-legislation provided for an incremental reshaping of inter-municipal cooperation, amalgamations and districts for local public services (Citroni, Lippi \& Profeti, 2015a). Conversely, LAs have gathered more cognitive resources and municipalities are now called for finding a new role through a more direct and committed involvement in inter-municipal cooperation.

Finally, the Regions/Local Authorities relations turned out to be the most prominent novelty: the Regions have been invested since the Delrio law in 2014 with the task of steering their subregional governance and got more power at the detriment of the provinces, which are slowly weakening; Metropolitan cities have been newly introduced, while inter-municipal cooperation and amalgamations have been strongly promoted. Evidence shows that only some Regions are effectively implementing the Delrio law and some changes are still only on paper (e.g., the full abolition of the provinces, the real boost of amalgamations, the effective subregional governance). More interestingly, Regions seem to have different strategies about their own territorial politics, confirming the increasing relevance of bargaining on this side of the game among territorial actors. Hence, the balance of power as far as political resources are concerned, goes along with a relatively stable legal framework and with a cognitive resource empowerment, while the still present financial pressure by the State undermines the chance for an autonomous and effective regional governance.

Looking at the evidence presented thus far under the light of Wallner's (2017) three Cs, competition seems to be the prominent relation between State and Regions, while the State/Local Authorities relations are characterized by a coercive behavior of the central State, gaining room of maneuver and restoring a sort of vertical approach. Instead, the Region/Local Authorities relation is moderately 
marked by cooperation, although some coercive strategies by the regions - or some competitive attitudes by the municipalities-may emerge as influential.

Some final remarks are worth mentioning. First, our evidence confirms that the changing IGRs in Italy did not lead to a definitive landing place: the Italian trilateral game may be in fact considered as a prominent case of change in the pattern, where change takes place by gradual evolution, and not through reforms. Its trend depicts a still provisional arrangement without any clear direction and a gradual incorporation of innovations by readjustments and games of power. The two failures in changing the Constitution, both toward more federalism (2005) and toward recentralization (2016) confirm this statement.

Secondly, the change in the pattern revealed to be sticky and ambiguous: the Overlapping Authority Model seems to be the fitting trend in the Italian case. The so-called quasi-federalism, started in 2001, resulted to be both dynamic and influenced by contingencies: as a result, the provisional and oscillating change is sticky and contradictory, subject to political contingencies and external policy windows. The trilateral game hence displays uncertainty and path dependency.

Furthermore, a side-effect seems to appear, which could be deepened in further researches. Despite the sticky and contradictory change in the pattern, that may result even entropic, this type of IGRs evolution seems nonetheless to have prevented widespread and harsher conflicts among the territorial actors and to have smoothed down disparities and differences; thanks to the continuous and persistent negotiations it implies. Tensions have thus been diluted and conflicts have been displaced and managed locally. In this perspective, the 2001 reform has been a sort of "safety valve," which canalized latent issues and absorbed the oscillation within the model, and never opened the way to radical centrifugal pressures. This aspect needs to be further explored also looking at other countries through comparative research. Nonetheless, the Italian trilateral game, with its uncertain and gradual institutional change in the pattern, is definitely ongoing and may turn out to be a leading analysis for comparative research on layered change and hybrid territorial arrangements.

Silvia Bolgherini is Assistant Professor at the University of Naples Federico II. Her research focuses on local government, comparative political systems, electoral studies.

Marco Di Giulio is a post-doctoral research fellow at the Polytechnic of Milan. His main research interests concern the governance of regulated sectors in Europe and the impact of technologies on public policies.

Andrea Lippi is Associate Professor of Political Science at the Department of Political and Social Sciences, University of Florence, Italy. His research interests concern policy instruments, policy evaluation, local governance, territorial rescaling.

\section{Note}

1. The rising of local political class is a long-term by-product of the introduction of the direct election for the mayors in 1993. Direct popular legitimacy and different competences put the mayors in a 
strong political position since. It is not by chance that in those years a movement (called Mayors' Party), a new powerful lobby of local interests and of "moral" renewal of political class, was born. It represented a new local leadership, which was also perceived as a moral renovation in a particularly turbulent political environment. Hence since the 1990s, mayors, especially those of the big cities, have played a forefront role in national policymaking.

\section{References}

Agranoff, R. 2001. "Managing with the Matrix: Do Collaborative Intergovernmental Relations Exist?" Publius 31 (2): 31-56.

-. 2014. "Local Governments in Multi-Level System: Emergent Public Administration Challenges." American Review of Public Administration 20 (10): 1-16.

Agranoff, R., and B. A. Radin. 2015. “Deil Wright's Overlapping Model of Intergovernmental Relations: The Basis for Contemporary Intergovernmental Relationships." Publius 45 (1): 139-59.

Alcantara, Ch, J. Broschek, and J. Nelles. 2016. "Rethinking Multilevel Governance as an Instance of Multilevel Politics: A Conceptual Strategy." Territory, Politics and Governance 4 (1): 33-51.

Ambrosanio, M.F., P. Balduzzi, and M. Bordignon. 2015. “Economic Crisis and Fiscal Federalism in Italy." In Multi-level Finance and the Euro Crisis, ed. E. Ahmand, M. Bordignon, and G. Brosio. Cheltenham: Edward Elgar, 212-46.

Bakvis, H. 2013. ““In the Shadows of Hierarchy”: Intergovernmental Governance in Canada and in the European Union." Canadian Public Administration 56 (2): 203-18.

Baldersheim, H., and L. Rose. (Eds.) 2010. Territorial Choice: The Politics of Boundaries and Borders. London: Palgrave.

Baldi, B., and F. Tronconi. 2011. "Between the center and the periphery: The regional elections and the path to fiscal federalism." Italian Politics 26 (1): 122-40.

Baldi, B., and G. Xilo. 2012. "Dall'Unione alla fusione dei Comuni: le ragioni, le criticità e le forme." Istituzioni del federalismo: rivista di studi giuridici e politici (1): 141-65.

Baldini, G., and B. Baldi. 2014. “Decentralization in Italy and the Troubles of Federalization." Regional and Federal Studies 24 (1): 87-108.

Behnke, N., and A. Benz. 2008. "The Politics of Constitutional Change between Reform and Evolution." Publius 39 (2): 213-40.

Behnke, N., and S. Kropp. 2016. "Arraying Institutional Layers in Federalism Reforms: Lessons from the German Case." Regional and Federal Studies 26 (5): 585-602.

Behnke, N., B. Petersohn, A. Fischer-Hotzel, and D. Heinz. 2011. "Measuring Success of Constitutional Reforms: Evidence from Territorial Reforms in Eight Western Democracies." Regional and Federal Studies 21 (4-5): 447-77.

Benz, A. 2016. “Gradual Constitutional Change and Federal Dynamics - German Federalism Reform in Historical Perspective." Regional and Federal Studies 26 (5): 707-28.

Benz, A., and J. Broschek, eds. 2013 Federal Dynamics: Continuity, Change and the Varieties of Federalism. Oxford, UK: Oxford University Press.

Biela, J., A. Henni, and G. Zons. 2014. “Between Deadlock and Decentralization: Bargaining Dynamics in Federal States." Regional and Federal Studies 24 (4): 505-25.

Bobbio, L. 2005. "Italy: After the Storm." In Comparing Local Governance, ed. B. Denters, and L.E. Rose. New York, NY: Palgrave, 29-46.

Bolgherini, S. 2014. “Can Austerity Lead to Recentralisation? Italian Local Government During the Economic Crisis." South European Society and Politics 19 (2): 193-214.

Bolgherini, S. 2015. Navigando a vista. Bologna, Il Mulino: Governi locali in Europa tra crisi e riforme.

- 2016. "Crisis-driven Reforms and Local Discretion. An Assessment of Italy and Spain." Italian Political Science Review 46 (1): 71-91. 
Bolgherini, S., Casula M., and M. Marotta. 2017. “Pursuing Defragmentation: Signs of a Changing Pattern?" Modern Italy 1-18, First view. https:/ / doi.org/10.1017/mit.2017.44.

Bolgherini, S., and A. Lippi. 2016. "Italy. Remapping Local Government from Re-Allocation and ReShaping to Re-Scaling." In Handbook of Research on Comparative Politics and Reformation in Local Governments, ed. U. Sadioglu, and K. Dede. Hershey, PA: IGI, 265-87.

Bolgherini, S., A. Lippi, and S. Maset. 2016. In mezzo al guado. La governance subregionale tra «vecchie» province e «nuove» aree vaste, in Rivista Italiana di Politiche Pubbliche, (XI), 3/2016, pp. 341-372.

Bordignon, M., M. Galamerio, and G. Turati. 2014. Così il decentramento ha cambiato la classe politica, la Voce.info, August 21. http://www.lavoce.info/archives/29457/cosi-decentramento-cambiatoclasse-politica/. Accessed February 12, 2018.

Brunazzo, M. 2009. “Da stato unitario a stato federale: territorializzazione della politica, devoluzione e adattamento istituzionale in Europa." Italian Politics \& Society 68: 33-4.

Brunazzo, M. 2010. “Italian Regionalism. A Semi-federation is Taking Shape - Or Is It?” In Territorial Choice, ed. H. Baldersheim, and L.E. Rose. Basingstoke: Palgrave, 180-96.

Bull, M., and M. Rhodes. 2007. "Italy: A Contested Polity." West European Politics 30 (4): 657-69.

Bussu, S., and M. T. Galanti. 2015. "I governi locali al tempo della crisi." In Politica in Italia 2015, ed. C. Hanretty, and S. Profeti. Bologna: il Mulino, 155-73.

Capano, G., and S. Vassallo. 2003. La dirigenza pubblica: il mercato e le competenze dei ruoli manageriali. Soveria Mannelli: Rubbettino.

Citroni, G., A. Lippi, and S. Profeti. 2015a. "Representation through Corporatization. Municipal Corporations in Italy as Arenas for Local Democracy." European Political Science Review 7 (1): 63 92.

—. 2015b. “Il governo regionale dei servizi pubblici locali: quali strumenti?” Le Regioni 4: 903-36.

Conlan, T. 2017. "Intergovernmental Relations in a Compound Republic: The Journey from Cooperative to Polarized Federalism." Publius 4 (2): 171-87.

Corte dei Conti. 2016. Relazione sulla gestione finanziaria delle Regioni. Esercizio 2014, Deliberazione no. 7/SEZAUT/2016/FRG.

Dente, B. 1997. “Sub-national Governments in the Long Italian Transition." West European Politics 20 (1): 176-93.

— 2012. “End of an Era? The Monti Government Approach to Central-local Relations." LIEPP Working papers, Paris Sciences Po.

Di Giulio, M., and S. Profeti. 2016. “Eppur si muove? Il riordino territoriale oltre la crisi." Rivista italiana di Politiche Pubbliche 11 (3): 311-40.

Diamanti, I. 2003. "Il ritorno dello Stato. L'Italia, dal regionalismo al neocentralismo." In Sistemi locali e spazio europeo, ed. P. Messina. Roma: Carocci, 228-45.

Dinan, D. 2012. “Governance and Institutions: Impact of the Escalating Crisis." Journal of Common Market Studies 50 (Suppl 2): 85-98.

Dyson, K. 2012. “"Maastricht Plus”: Managing the Logic of Inherent Imperfections.” Journal of European Integration 34 (7): 791-808.

Elazar, D. J. 1964. “Federal State Collaboration in the nineteenth Century United States." Political Science Quarterly 79 (2): 248-81.

Fraune, C., and M. Knodt. 2017. “Challenges of Citizen Participation in Infrastructure Policy-Making in Multi-Level Systems - The Case of Onshore Wind Energy Expansion in Germany." European Policy Analysis 3 (2): 256-73.

Gerring, J. 2007. Case Study Research: Principles and Practices. Cambridge: Cambridge University Press.

Hoffmann-Martinot, V., and H. Wollmann. 2006 State and Local Government Reforms in France and Germany. Divergence, and Convergence. Wiesbaden: Springer. 
Hopkin, J. 2003. "Political Decentralization, Electoral Change and Party Organizational Adaptation: A Framework for Analysis." European Urban and Regional Studies 10 (3): 227-37.

Hoppe, R. 2017. “Lindblom on Limits to Policy Change: The Tragic Dilemma between Understanding and Shaping the World." European Policy analysis 3 (2): 226-55.

Ignazi, P., and E. Pizzimenti. 2014. “The Reins of Intra-party Power in the Italian Political Parties (1990-2011)." Rivista italiana di scienza politica 44 (3): 223-46.

Ingold, K., and G. Pflieger. 2016. “Two Levels, Two Strategies: Explaining the Gap between Swiss National and International Responses Toward Climate Change." European Policy Analysis 2 (1): 2238.

ISTAT. 2014. I bilanci consuntivi delle Regioni e Province autonome. http://www.istat.it/it/archivio/ 125870. Accessed September 15, 2017.

Keating, M. 2013. Rescaling the European State. The making of Territory and the Rise of the Meso. Oxford: Oxford University Press.

Kincaid, J. 1990. "From Cooperative to Coercive Federalism." The Annals of the American Academy of Political and Social Science 509: 139-52.

Kropp, S., and N. Behnke. 2016. "Marble Cake Dreaming of Layer Cake: The Merits and Pitfalls of Disentanglement in German Federalism Reform." Regional and Federal Studies 26 (4): 667-86.

Kuhlmann, S., and H. Wollmann. 2014. Introduction to Comparative Public Administration: Administrative System and Reforms in Europe. London: Elgar Press.

Lippi, A. 2003. As a voluntary choice or as a legal obligation: Assessing new public management policy in Italy. In Evaluation in public sector reform, ed. H. Wollmann. Concepts and practice in international perspective. Cheltenham: Edward Elgr, 140-168.

2011. "Evaluating the "Quasi Federalist" Programme of Decentralisation in Italy Since the 1990s: A Side-effect Approach." Local Government Studies 37 (5): 495-516.

Mahoney, J., and K. Thelen. 2010. “A Theory of Gradual Institutional Change." In Explaining Institutional Change. Ambiguity, Agency, and Power, ed. J. Mahoney, and K. Thelen. Cambridge: Cambridge University Press, 1-37.

Marinuzzi, G., and W. Tortorella. 2014. “Lo stato dell'arte delle fusioni in Italia." Amministrare 54 (1): 149-60.

Mauri, E., and G. C. Ricciardi. 2015. "Nuove prospettive di valorizzazione delle aggregazioni territoriali? L'esperienza lombarda delle fusioni comunali nel contesto macroregionale alpino." Le Regioni 43 (4): 985-1012.

Musella, F. 2009. Governi monocratici. Bologna: Il Mulino.

Petersohn, B., N. Behnke, and E. M. Thode. 2015. “Negotiating Territorial Change in Multinational States: Party Preferences, negotiating Power and the Role of the Negotiation Mode." Publius 45 (4): 626-52.

Piattoni, S., and M. Brunazzo. 2010. "Italy: The Subnational Dimension to Strengthening Democracy Since the 1990s." In The Oxford Handbook of Local and Regional Democracy in Europe, ed. A. L. Frank Hendriks, and J. Loughlin. Oxford: Oxford University Press, 331-55.

Posner, P. 2007. "The Politics of Coercive Federalism in the Bush Era." Publius: The Journal of Federalism 37 (3): 390-412.

Rumpianesi, D. 2014. “La fusione dei Comuni Valsamoggia. L'Assemblea Costituente per la definizione dello Statuto e dei Municipi elettivi." Le Istituzioni del federalismo 35 (2): 465-91.

Sandford, M. 2016. "Signing Up to Devolution: The Prevalence of Contract over Governance in English Devolution Policy." Regional and Federal Studies 27 (1): 63-82.

Santoro, P. 2014. Deboli ma forti. Il pubblico impiego in Italia tra fedeltà politica e ammortizzatore sociale. Milano: Franco Angeli.

Scharpf, F. W. 1997. Games Real Actors Play: Actor-centered Institutionalism in Policy Research. Boulder: Westview Press. 
Sharpe, L. J. 1993. The Rise of the Meso Government in Europe. London: Sage.

Tarrow, S. 1977 Between Center and Periphery: Grassroots Politicians in Italy and France. New Haven, CT: Yale University Press.

Thorlakson, L. 2009. "Patterns of Party Integration, Influence and autonomy in Seven Federations." Party Politics 15 (2): 157-77.

Toth, F. 2014. La sanità in Italia. Bologna: il Mulino.

Tubertini, C. 2010. “Le Regioni e il sistema delle Conferenze: riflessioni sulle possibili riforme." Le Istituzioni del federalismo 1 (2): 93-111.

- 2012. “La razionalizzazione del sistema locale in Italia: verso quale modello?” Istituzioni del federalismo: rivista di studi giuridici e politici (3): 695-725.

Van Biezen, I., and J. Hopkin. 2015. "Party Organization in Multi-Level Context: Theory and Some 2 Comparative Evidence." In Devolution and Electoral Politics, ed. D. Hough, and Ch. Jeffery. Manchester, UK: Manchester University Press, 14-36.

Vandelli, L. 2012. "Local Government in Italy." In Local Government in the Member States of the European Union: A Comparative Perspective, ed. A.M. Moreno Molina. Madrid, Spain: INAP, 339-64.

Vassallo, S. 2015. I quattro pilastri per una nuova governance regionale. Bologna: Dipartimento di scienze politiche e sociali.

Wallner, J. 2017. “Cooperation Without the Leviathan: Intergovernmental Policy making in Canadian Education." Regional and federal Studies 27 (4): 417-40.

Wright, D. S. 1988. Understanding Intergovernmental Relations. Pacific Grove, CA: Brooks-Cole. 